\title{
PERANCANGAN PERTUNJUKAN TEATER LAKON "SENJA DENGAN DUA KELELAWAR" KARYA KIRDJOMULYO
}

\author{
Megi Hardani, Yusril, dan Nursyirwan \\ Pascasarjana Institut Seni Indonesia Padangpanjang, Indonesia \\ Email: redaksiMAPJ@gmail.com, No. Hp: 081234254702
}

\begin{abstract}
Kirdomulyo's theatrical play called "Senja Dengan Dua Kelelawar" (translated loosely as "An Evening With A Pair Of Bats") demostrates a creation process of play script which is translated into a theatrical performance. The creation process started with a concept, methodology and the overall packge of theatrical performance.

The overal process of Kirdomulyo's "Senja Dengan Dua Kelelawar" play started wtih a deep analysis on the scrript (both structural or texture of the play). This is followed by the design formation of the overal theatrical performance with a style that put emphasize on the reality of day to day lives as a foothold
\end{abstract}

Key words: play, structure and texture, realistic

\begin{abstract}
ABSTRAK
Perancangan teater lakon "Senja Dengan Dua Kelelawar" karya Kirdjomulyo merupakan proses penciptaan teks lakon menuju pemanggungan atau pertunjukan teater. Proses penciptaan ini diawali dengan perancangan pertunjukan yang berisi tentang konsep, metode, dan perwujudannya di atas panggung.

Perwujudan perancangan lakon Senja Dengan Dua Kelelawar karya Kirdjomulyo dalam sebuah pementasan teater diawali dengan melakukan analisis terhadap teks baik analisis struktur maupun tekstur lakon. Langkah tersebut ditindak lanjuti dengan perancangan bentuk pementasan dengan mengacu pada gaya lakon yakni gaya realisme. Gaya realisme adalah gaya dalam pertunjukan teater yang dihadirkan melalui dengan menjadikan realitas sehari-hari sebagai pijakan.
\end{abstract}

Kata kunci: lakon, struktur dan tekstur, realisme

\section{PENDAHULUAN}

Faktor yang lebih mendasar untuk mewujudkan pementasan adalah keberadaan naskah lakon. Segala perwujudan pentas pada dasarnya berangkat dari penafsiran sutradara terhadap lakon. Pemilihan naskah lakon dengan demikian menjadi landasan yang pen- ting untuk mencari kemungkinan-kemungkinan artistik yang akan dipentaskan. Naskah lakon "Senja dengan Dua Kelelawar" karya Kirdjomulyo menjadi pilihan pencipta dengan berbagai pertimbangan dan daya tarik yang melatarinya. 
Lokon Senja Dengan Dua Kelelawar Karya Kirdjomulyo (Tokoh Teater Muslim Yogyakarta) menceritakan suatu konflik yang terjadi di sebuah stasiun kereta api (sekaligus sebagai latar cerita), antara sepasang kekasih yang ternyata hidup dalam pengaruh orang-orang 'didekatnya' baik yang hadir dalam kenyataan hari ini maupun di masa lalu. Lakon tersebut menceritakan suatu pembunuhan seorang gadis (seseorang yang telah memilki kekasih baru) yang dilakukan oleh seorang kekasih lama (yang telah dikhianati di masa lalu) yang sekaligus membuka tabir bahwa 'kemanisan' sikap ternyata menyimpan 'racun' yang bisa mengelabuhi siapapun. Disisi lain, seseorang yang terkadang tersia-siakan rasa cintanya ternyata justru memiliki ketulusan cinta yang mendalam. Lakon Senja dengan Dua Kelelawar juga menegaskan satu premis: bahwa nilai manusia tidak bisa dilihat dari 'permukaan' tetapi hanya bisa disimpulkan dari prilakunya dalam keseharian. Lakon ini menegaskan bahwa ketulusan cinta ternyata tidak sesederhana tutur kata, kehangatan sikap, perhatian berlebih dan kalimat-kalimat menghibur tetapi juga kesediaan untuk berkorban dan kerelaan untuk menerima orang yang dicintainya tersebut secara apa adanya. Inilah universalitas nilai yang sebenarnya sangat menarik untuk di kedepankan terlebih untuk meng-aksentuasikan nilai-nilai islami sebagai karakter paling hakiki dalam spirit ke-Melayuan.
Dengan menghadirkan alur certa yang terlihat sangat dinamik dan penokohan yang beragam sekaligus kompleks, maka penyutradaran lakon "senja dengan Dua Kelelawar" karya Kirdjomulyo ini sangat menuntut kejelian dan ketelitian. Dua aspek tersebut sangat penting mengingat lakon ini merupakan lakon yang dapat digolongkan dalam Well Made Play, yakni suatu drama yang disajikan dengan karakter penokohan yang jelas, progresi alur yang selalu memiliki tahapan meningkat dan jalinan konflik dengan ketegangan yang yang dinamik. Bentuk Well Made Play ini dengan sendirinya menempatkan lakon ini sebagai lakon yang berkategori lakon bergaya realisme, yakni suatu aliran lakon yang mencoba mengangkat "sepotong kehidupan" secara apa adanya ke atas panggung.

\section{STRUKTUR DAN TEKSTUR LAKON}

Lakon ini dimulai dengan menghadirkan keberadaan tokoh Ismiyati yang sedang dirundung kesedihan. Ia tak pernah bisa melupakan Suwarto, kekasihnya, yang telah mengkianatinya dan menikah dengan seorang gadis lain yang bernama Mursiwi. Ayahnya, Pak Marsudi, tak henti-hentinya memberi nasehat agar Ismiyati menerima kenyataan itu dan mulai memikirkan masa depannya, tetapi Ismiyati bergeming. Pak Marsudi pun terkejut, karena Ismiyati justru mengutarakan niatnya untuk membunuh Mursiwi yang telah merebut kekasihnya tersebut. 
Pada suatu malam, isteri Suwarto pun meninggal. Ia ditemukan tewas tertabrak kereta api yang melintas. Semua orangpun menuduh Ismiyati sebagai biang keladinya. Begitupun dengan pak Marsudi. Semula Ismiyati mengelak tetapi begitu didesak oleh Suwarto, akhirnya Ismiyati mengakui bahwa dirinyalah yang telah membunuh Mursiwi. Suwarto naik pitam dan bermaksud membunuh Ismiyati, tapi Suwarto ternyata tak sampai hati.

Di tengah kegalauan dan kebencian yang mengusai hati Suwarto munculah Sulaiman. Dialah yang kemudian mengakui sebagai pembunuh Mursiwi yang sebenarnya. Sulaiman melakukan itu karena hatinya dendam oleh pengkianatan Mursiwi terhadap dirinya. Dari Sulaiman lah, Suwarto akhirnya mengetahui bahwa Mursiwi bukan perempuan baik-baik.

Serentetan kejadian di atas, menyadarkan Suwarto betapa kecintaaan Ismiyati begitu besar. Sebuah perasaan yang berani mempertaruhkan apapun termasuk jiwanya sendiri. Hati Suwarto pun luruh. Ia merasa telah menyia-nyiakan perasaan Mursiwi yang sesungguhnya begitu tulus mencintainya.

Analisis struktur lakon adalah suatu langkah pemahaman terhadap keseluruhan unsur-unsur pembentuk struktur dramatik dalam naskah, sekaligus pencarian terhadap kemungkinan-kemungkinan tafsir dalam lakon. RMA Harymawan mengatakan bahwa tujuan analisis lakon adalah menyimpulkan dasar kesatuan pendirian dan pendapat unit yang akan membawa dalam kesatuan interpretasi (RMA Harymawan, 1984: 23-26). Kesatuan tafsir inilah yang pada akhirnya akan menjadi pijakan dalam menyusun desain-desain pemanggungan. Dengan demikian, proses analisis lakon, pembuatan desaindesain panggung merupakan mekanisme yang memiliki keterkaitan dalam usaha mewujudkan lakon sebagai kenyataan pentas.

Sebagai jalinan yang berstruktur, setiap unsur-unsur pembentuk lakonpun memiliki keterkaitan satu dengan yang lainnya. Merujuk hal tersebut maka analisis lakon dilakukan dalam kerangka mencari hubungan antar unsur-unsur tersebut sebagai sebuah jalinan yang memiliki keterkaitan. Adapun unsurunsur yang dimaksud meliputi: tema, penokohan, Alur, dan latar cerita.

\subsection{Tema}

Lakon terbentuk dari sebuah gagasan dasar yang mengarahkan dan menopang seluruh unsur-unsur pembentuk lakon. Gagasan dasar itulah yang lazim disebut sebagai tema. Sudiro Satoto menyebut tema sebagai dasar pikiran utama dan sumber ide yang mengawali terbentuknya lakon (Sudiro Satoto, 1988: 17). Sementara itu RMA Harymawan memahami tema dari sudut pandang watak manusia, yakni sebagai falsafah mendasar suatu obsesi yang fundamental (Panuti Sujiman,1988: 22). Merujuk pendapat-pendapat tersebut, dapat dipahami bahwa tema merupakan unsur awal yang akan mengilhami unsur-unsur lain dalam lakon. 
Panuti Sudjiman membagi tema menjadi dua jenis yakni: tema mayor dan tema minor. Tema mayor adalah tema yang menopang keseluruhan lakon, sedangkan tema minor adalah sub-sub tema yang dapat dipahami dari alur maupun penokohan yang ada. Tema mayor dalam naskah Senja dengan Dua Kelelawar adalah perasaan cinta yang tak bisa dinilai dari 'permukaan' atau segala sesuatu yang terlihat. Cinta terkadang melahirkan serangkaian tindakan yang penuh tipuan dan hasrat untuk menyenangkan satu sama lain, padahal semuanya hanya untuk menutupi ambisi dalam hati agar dapat 'mengusai' orang lain.

Tema minor pada lakon Senja dengan Dua Kelelawari karya Kirdjomulyo tercermin pada kehadiran tokohtokoh dalam lakon tersebut. Tokohtokoh dalam lakon Senja dengan Dua Kelelawari karya Kirdjomulyo ini memperlihatkan suatu perasaan cinta yang sering kali mengabaikan realitas dan tanpa mempertimbangkan akal jernih. Hal ini dapat dilihat dari sikap Ismiyati yang berani mempertaruhkan hidupnya dengan mengakui sebagai pembunuh Mursiwi untuk mengetahui seberapa besar cinta Suwarto pada almarhumah istrinya sekaligus mengukur seberapa besar kebencian Suwarto yang akan ditimpakan pada dirinya.

Progresi dramatik sebuah lakon tercipta oleh adanya kejadian demi kejadian yang membentuk jalinan. Setiap kejadian muncul karena serangkaian dialog yang menimbulkan progresi emosi dan perubahan suasana. Pada akhirnya jalinan kejadian (peristiwa) itulah yang kemudian membentuk alur cerita atau plot. Panuti Sudjiman memberikan batasan plot sebagai jalinan peristiwa dalam karya sastra (termasuk sastra drama) yang bertujuan untuk mencapai efek tertentu, terkait dengan: hubungan temporal (waktu) dan hubungan kausal (sebab akibat) (Panuti Sujiman, 1984: 4). Rangkaian peristiwa dalam alur dijalin dengan seksama melalui pergerakan cerita yang mengalami perumitan (komplikasi) kearah klimaks dan penyelesaian.

Berdasarkan hubungan temporal atau waktu, alur bisa berwujud alur maju (alur yang bergerak kedepan) dan alur mundur (gaya penceritaan yang kembali kebelakang atau di mulai datri peristiwa sebelumnya). Dua wujud alur tersebut menandakan bahwa alur bisa bergerak menanjak atau menurun dalam bentuk episodik dan tidak terpisahkan. Merujuk penjelasan tersebut maka lakon Bui karya Akhudiat memiliki alur maju dan bergerak secara linier.

Plot yang merupakan rangkaian kejadian membentuk jalinan yang terbagi dalam lima tahap, yaitu; eksposisi (pelukisan), komplikasi (perumitan masalah atau peristiwa), klimaks (puncak peristiwa), resolusi (peleraian) dan konklusi (penyelesaian). Hal di atas adalah alur yang diteorikan oleh Aristoteles, yang biasa disebut sebagai alur konvensional (RMA Harymawan,1984: 47).

Eksposisi (pelukisan) adalah penjelasan awal atau permulaan dalam cerita yang akan disampaikan. Kom- 
plikasi (perumitan masalah) adalah permasalahan cerita yang semakin terlihat dengan ditandai interaksi tokohtokoh dalam cerita yang semakin jelas. Klimaks (puncak konflik) adalah ketegangan paling puncak dalam lakon yang ditandai dengan kejadian paling kritis. Resolusi (peleraian) adalah menurunnya ketegangan menuju penyelesaian akhir, sedangkan konklusi (penyelesaian) adalah akhir dari keseluruhan permasalahan. Pendapat Aristoteles ini dipertegas oleh Gustav Freytag yang membagi progresi alur menjadi enam tahapan, yaitu dengan menambahkan tahapan: penyelesaian yang baik (Catastrope) (Sudiro Satoto, 1988: 17).

Alur dalam naskah Senja dengan Dua Kelelawar karya Kirdjomulyo terbentuk melalui dinamika yang diakibatkan oleh perubahan emosi para tokohnya. Perubahan emosi itu memiliki progresi karena respon terhadap prilaku dan sikap tokoh dalam lakon yang semakin memperumit persoalan. Progresi emosi itulah yang kemudian melahirkan perjalanan alur dari permulaan yang terlihat sederhana menuju pada kondisi yang lebih kritis. Dalam alur yang berjalan itu maka naskah Senja dengan Dua Kelelawar karya Kirdjomulyo dapat disimpulkan menggunakan alur yang konvensional (linier). Tahaptahap alur (konvensional) dalam naskah Senja dengan Dua Kelelawar tersebut dapat dijelaskan sebagai berikut:

Eksposisi: Dimulai pada adegan awal, ketika pak Marsudi menasehati Ismiyarti agar belajar mencintai seorang pemuda yang bernama Marjuki dan segera melupakan Suwarto. Ismiyarti menolak bahkan meminta ayahnya untuk tidak mencampuri urusan pribadinya. Selengkapnya, dapat dilihat dari kutipan dialog di bawah ini:

Marsudi : Ia mengajak jalan-jalan ke Kaliurang besok minggu. Kalau kita mau. (Pause) Ia sungguh menaruh hati padamu.

Ismiyati : Bapak sudah tahu apa kirakira jawabanku...

Marsudi : Pertimbangkanlah. Ia cukup dewasa untuk menjadi suami dan bapak dari anakanakmu kelak. Ia juga cukup kaya untuk hidup berumah tangga. Cukup baik budinya, Cukup besar baktinya pada masyarakat, cukup sesuai dengan kau...

Ismiyati : Cukup apa lagi? (Marsudi tersinggung karena mersa diabaikan). Cukup banyak memberi apa kepada Bapak? (makin keras perkataannya) Bapak sudah tahu bahwa aku tidak pernah mencintainya. Tidak pernah! tidak pernah mencintai orang lain. (berpaling ke tiang, menahan) Bapak sudah tahu semuanya.

Marsudi : Aku tahu penderitaanmu. Aku tahu kau mencintai Suwarto, tapi apa gunanya mencintai orang yang sudah beristri? Ia sudah kawin. Tiap sore kau berdiri 


\author{
di sini. Untuk apa? Apa \\ gunanya? kalau toh kau \\ bisa merebut hatinya dari \\ Mursiwi. Itu akan meng- \\ hancurkan kehidupan Mur- \\ siwi. \\ Ismiyati : Peduli apa pada penderita- \\ an orang lain? Bapak ha- \\ rusnya tahu, aku lebih du- \\ lu mencintainya.
}

Komplikasi: Tahapan ini terjadi pada saat terjadinya pembunuhan Mursiwi yang menimbulkan kecurigaan besar dalam diri pak Marsudi pada Ismiyati. Ismiyati mengelak dari tuduhan ayahnya. Pak Marsudi tetap berkeyakinan bahwa Ismiyati lah yang menjadi pembunuh Mursiwi. Ia menyesal dan kecewa berat. Secara lebih jelas, hal ini dapat dibaca dari kutipan dialok di bawah ini:

\section{Marsudi : Kau tidak menyuruh? \\ Ismiyati : Aku tidak menyuruh. Aku juga tidak tahu kenapa orang itu membunuh Mur- siwi. Demi Tuhan, itu tidak ada hubungannya dengan- ku. (mengeras dan me- nangis menelungkup di bangku)}

Marsudi : (Ragu-ragu, terdududk dan memandang rel yang memanjang di depannya). Kau membohongi ayah Is! Kau tidak bisa mengelak! Apa kata almarhum ibumu karena aku telah gagal mendidikmu... Gusti
Allah... aku telah memiliki anak seorang pembunuh!

Klimak: Tahapan ini terjadi ketika Suwarto mendengar pengakuan Ismiyati bahwa dirinyalah yang telah membunuh Mursiwi. Suwarto merasa sok dan berniat membunuh Ismiyati meskipun niat itu ia urungkan. Hal ini dapat dibaca pada kutipan dialog di bawah ini:

Suwarto : Demi Tuhan, Katakan Is!

Ismiyarti : Akulah yang membunuh isterimu. (pause) Sekarang terserah kau. Aku hanya ingin kau bisa melupakan isterimu. Sejak dulu aku tak pernah berubah. Aku selalu menyayangimu. Sekarang terserah kau, apa yang akan kau lakukan padaku...

Suwarto : Kau! (Berubah lirih) Apa yang akan aku lakukan padamu (mondar-mandir, dan berguman berulangulang. Lalu berteriak dan mencengkeram baju Ismiyati secara tiba-tiba) Apa yang akan aku lakukan padamu, apa yang harus aku lakukan padamu, katakan!

Ismiyati : (Dalam cengkeraman Suwarto) Lakukan lah sesuka hatimu! Aku hanya ingin hidup bersama denganmu

Suwarto : Aku hidup dengan seorang pembohong! Hidup deng- 
an seorang pembunuh!

Ismiyati : Aku rela menjadi pembohong seumur hidup. Mempertaruhkan apa saja yang aku miliki, demi dapat hidup bersama dengan orang yang kucintai.

Suwarto : Oo.. begitu, aku ingin tahu seberapa besar kau memiliki nyali untuk mempertaruhkan hidupmu demi orang yang kau cintai. Aku ingin lihat. Ayo tunjukan nyalimu! Tunjukan kalau kau mencintaiku! (Suwarto menarik kedua tangan Ismiyati ke belakang dan mendorongnya ke arah suara kereta api yang terdengar mendekati tempat itu)

Resolusi: Tahapan ini terjadi ketika Sulaiman datang dan mengatakan bahwa dirinyalah yang telah membunuh Mursiwi. Ia katakan bahwa semua itu ia lakukan sebagai pembalasan dendam atas pengkianatan yang dilakukan Mursiwi. Hal ini dapat dibaca pada kutipan dialog di bawah ini:

Ismiyati : Aku tak memaksamu untuk menentukan pilihan itu. Tapi kalau kau merasa tak nyaman selama aku masih berada di dekatmu, sekarang aku akan melapor ke Polisi. Aku akan habiskan hidupku di penjara. Aku berbahagia su- dah mengatakannya. Tapi percayalah sampai kapanpun aku akan menunggumu, To... (Keduanya berpandangan, tiba-tiba munculah Sulaiman yang menyela keheningan mereka berdua). Aku akan ke kantor Polisi...

Sulaiman : Bukan kau yang harus menyerahkan diri ke Polisi, tapi akulah orangnya. (Suwarto terkejut) Akulah yang mendorong Mursiwi hingga menemui ajalnya. Ismiyati tidak melakukan kesalahan apapun. Mursiwi memang pantas dimatikan dari kehidupan kita. Banyak orang yang telah menjadi korbannya. Ia tidak pernah mencintai orang dengan benar. Seluruh perbuatannya digerakkan oleh keinginan untuk memenuhi ambisinya sendiri. Kau mestinya tahu To... dua hari yang lalu Mursiwi menemuiku dan meminta begitu banyak uang padaku yang katanya untuk memenuhi kebutuhan segala pernikahan kami, dua hari kemudian akhirnya aku tahu bahwa semua itu dusta...

Konklusi: Tahap ini terjadi di akhir lakon, ketika Suwarto mulai 
menyadari betapa besar dan tulus cinta yang dimiliki oleh Ismiyati terhadap dirinya. Ia merasa selama ini telah menyia-nyiakan begitu banyak perhatian Ismiyati. Hal ini dapat dilihat dari kutipan dialog di bawah ini:

Suwarto : Tanpa aku sadari, aku sudah melakukan pengkianatan.

Ismiyati : Mungkin karena aku terlalu apa-adanya sehingga sangat menjemukan.

Suwarto : Aku juga tak sanggup bertaruh diri..

Ismiyati : Tapi aku yakin sekarang mas Warto akan sanggup menerimaku apa-adanya...

\subsection{Penokohan}

Penokohan merupakan pemaparan karakter tokoh menyangkut kualitas, ciri atau sifat-sifatnya sebagai hasil penafsiran dalam lakon. Pemahaman tokoh denganm demikian adalah analisis terhadap identitas tokoh-tokoh dalam lakon. Adapun penokohan dalam lakon Senja dengan Dua Kelelawar dapat dijabarkan sebagai berikut:

a. Ismiyati

Tidak ada penggambaran khusus dan spesifik mengenai fisik tokoh Ismiyati yang dapat ditemukan dalam lakon. Dari serangkaian dialog, dijelaskan bahwa Ismiyati adalah seorang gadis yang usianya berada pada kisaran siap untuk berumah tangga. Dalam dialog antara Sutomo dan Siswoyo dinyatakan pula bahwa Ismiyati adalah seorang gadis yang berparas manis.

Ismiyati adalah anak semata wayang pak Marsudi. Ia dibesarkan oleh pak Marsudi yang menghidupi diri dari gaji pensiunan. Gambaran ini juga menunjukan keberadaan Ismiyati sebagai bagian keluarga kelas menengah yang memiliki pendidikan memadai.

Jika merujuk pada pernyataan-pernyataan Ismiyati ketika berdialog dengan tokoh-tokoh lain, maka dapat disimpulkan bahwa Ismiyati adalah perempuan yang selalu memegang teguh pendiriannya. Ia juga terperangkap pada cintanya yang begitu besar pada Suwarto sehingga seringkali tidak pernah memperdulikan realitas yang diterimanya: bahwa Suwarto telah menjadi milik orang lain. Diluar itu, Suwarti sesungguhnya adalah gadis yang selalu iklas berkorban dan sangat peduli pada keberadaan orang lain, cintanyalah yang membuat hatinya terkadang gelap.

\section{b. Pak Marsudi}

Dalam lakon tidak dijelaskan ciri-ciri khusus fisik pak Marsudi. Diantara tokoh-tokoh yang dihadirkan, pak Marsudi adalah tokoh yang dianggap paling sepuh. Merujuk anaknya yang sudah dewasa dan siap menikah, maka bisa dipastikan bahwa usia pak Marsudi berada di kisaran di atas 60-an. 
Pak Marsudi adalah ayah dari Ismiyati. Merujuk pada kesukaannya yang lebih banyak bersantai, ketika tokoh-tokoh yang lain bekerja, maka bisa disimpulkan bahwa pak Marsudi adalah seorang pensiunan pegawai Jawatan Kereta Api. Gaya hidupnya yang selalu bersikap rileks menunjukan bahwa keseharianya tidak mengalami himpitan secara ekonomi. Dengan demikian ia adalah seorang yang 'mapan', meskipun bukan seorang yang kaya raya.

Pak Marsudi adalah ayah dikenal sangat sabar dan penyayang bagi anaknya, Ismiyati. Sebagai pribadi yang sekian lama telah menduda, ia juga dikenal sebagai sosok yang sangat perhatian pada lingkungan sekitarnya. Rasa sayangnya pada Ismiyati yang berlebih membuat jiwanya tergoncang ketika mendengar kabar kematian Mursiwi. Ia meyakini anaknyalah yang menyebabkan kematian Mursiwi.

c. Suwarto

Dari penjelasan Ismiyati yang menyatakan bahwa pernikahan suwarto dan Mursiwi belum berselang lama dapat ditarik kesimpulan bahwa Suwarto adalah sosok yang masih berusia muda. Sementara itu, dari ketertarikan Mursiwi dan cinta berlebih Ismiyati pada Suwarto dapat disimpulkan bahwa Suwarto sesungguhnya adalah sosok yang memiliki daya tarik secara fisik (tampan dan gagah).
Peristiwa penjemputan Mursiwi saat Suwarto pulang kerja dan rencana Suwarto yang akan bertamasya ke Kaliurang menunjukan bahwa Suwarto sesungguhnya telah memiliki kehidupan yang mapan. Selain itu, merujuk penjelasan pak Marsudi dalam dialognya dengan Ismiyati tentang pesan-pesan keluarga Suwarto pada pak Marsudi agar turut membimbing Suwarto menunjukan bahwa kehidupan keluarga Suwarto setara dengan keluarga Ismiyati yakni berasal dari kehidupan sekmen 'menengah'.

Di balik ketenanganya, Suwarto adalah pribadi yang temperamental. Cintanya yang begitu besar pada mendiang isterinya membuatnya tak bisa memaafkan pembunuh istrinya tersebut. Hatinya beku dan tak bisa mencintai siapapun. Tetapi, dibalik pribadinya yang emosianal terebut, Suwarto sesungguhnya adalah manusia yang setia. Hatinya mudah tergugah. Ia juga pribadi yang bertanggung jawab.

\section{d. Mursiwi}

Dari dialog terakhir Sulaiman yang menjelaskan alasannya untuk membunuh Mursiwi dapat diketahui bahwa Mursiwi adalah wanita berparas molek. Mursiwi juga diperkirakan berusia sepantaran Ismiyati. Hal tersebut dapat disimak dari perbincangan mereka yang samasama memanggil nama dan bukan sebutan kakak (mbak). Kemolekan 
Mursiwi juga tidak sekedar ditunjukan dari fisik tetapi juga tercermin dari penampilannya yang lebih 'menggoda'.

Dalam lakon tidak ditemukan penanda yang tegas mengenai asalusul Mursiwi. Dari pengakuan Sulaiman akhirnya diketahui bahwa Mursiwi adalah seorang 'petualang'. Sikap hidupnya yang senang 'berpetualang tersebut sepertinya menegaskan bahwa masa lalu Mursiwi tidak memiliki 'kemapanan' secar ekonomi.

Mursiwi adalah wanita yang ambisius dan sangat mencintai kesenangan. Hal tersebut dapat dapat disimak dari pengakuan Sulaiman tentang petualangan Mursiwi yang berganti-ganti pasangan. Lewat pengakuan tersebut juga diketahui kalau Mursiwi juga dikenal sebagai wanita 'perayu'. Ia juga berperangai egois karena tak pernah merasa bersalah untuk meninggalkan begitu saja para kekasih terdahulunya.

e. Tokoh-tokoh Pembantu (Mardikun, Tomokaryo dan Siswoyo) Tokoh-tokoh seperti Mardikun, Tomokaryo dan Siswoyo adalah tokoh-tokoh yang dihadirkan untuk menegaskan atmosfer cerita, yakni kehidupan di sekitar Stasiun Kereta api. Mereka adalah para pegawai di lingkungan jawatan kereta api. Kehadiran mereka seringkali bertindak sebagai tokoh penengah (tritagonis) dan penetralisir kejadian. Mereka juga dikenal sebagai sahabat-sahabat pak Marsudi yang hidup berdampingan dan saling membantu tatkala dirundung persoalan.

Dalam lakon Senja dengan

Dua Kelelawar juga ditemukan pengkategorian tokoh dalam bentuk antagonis maupun protagonis. Mereka yang bisa dikategorikan sebagai tokoh protagonis (pengusung cita-cita mulia) adalah Ismiyati, Marsudi dan Suwarto. Sedangkan yang dapat digolongkan dalam tokoh-tokoh antagonis (lawan dari protagonis) adalah: Mursiwi dan Sulaiman.

\subsection{Latar Cerita}

Latar cerita adalah berbagai persoalan yang terkait dengan hal-hal yang melandasi atau menjadi bagian dari peristiwa, tempat terjadinya peristiwa dan kurun waktu yang terjadi dalam lakon. Pemahaman latar cerita ini dimaksudkan untuk memahami keseluruhan cerita sebagai pijakan untuk diwujudkan dalam realitas panggung (Jakob Sumardjo, 1981: 14). Merujuk hal tersebut maka latar cerita dalam lakon Senja dengan Dua Kelelawar dapat dijelaskan sebagai berikut:

\section{a. Latar Ruang}

Latar ruang dalam lakon Senja dengan Dua Kelelawar adalah lingkungan sekitar stasiun kereta api. Jika merujuk dari penamaan para tokoh dalam lakon maka bisa dipastikan bahwa stasiun tersebut adalah sebuah stasiun kereta api di 
kota-kota Jawa Tengah (Yogyakarta, Solo, Semarang). Gambaran detail mengenai lingkungan stasiun kereta api tersebut adalah adanya petunjuk dalam lakon mengenai keberadaan rel kereta api, dan beberapa buah kursi untuk bercengkerama dan terdengarnya deru kereta api yang muncul dalam beberapa adegan dalam lakon. Disamping itu lewat beberapa dialog (antara Suwarto dan Mardikun) dapat disimak keberadaan pak Mardikun yang bekerja sebagai pegawai di stasiun tersebut.

\section{b. Latar Waktu}

Kurun waktu dalam lakon Senja dengan Dua Kelelawar tidak menjelaskan secara pasti kapan peristiwa terjadi, artinya kejadian demi kejadian dalam lakon tidak mengarah pada waktu tertentu. Keberadaan naskah yang seperti ini, memungkinkan untuk ditafsir dalam kurun waktu ke belakang atau pada masa kekinian. Pun begitu dari berbagai dialog tokoh-tokohnya terlihat secara jelas bahwa sebagian besar kejadian-kejadian tersebut berlangsung di malam hari.

Dialog adalah percakapan yang terjadi antara tokoh satu dengan tokoh yang lain dalam sebuah lakon (Suyatna Anirun, 1993: 39). Dialog selain berfungsi memberikan informasi tentang karakter tokoh, juga berperan dalam menciptakan alur cerita, menegaskan tema, latar cerita juga menentukan tempo atau irama permainan. Dialog dalam lakon Senja dengan Dua Kelelawar karya Kirdjomulyo adalah dialog yang bersifat keseharian. Dialog kesehariah adalah dialog yang lasim digunakan dalam pergaulan sehari-hari sehingga sama sekali meniadakan bahasa simbol atau bahasa yang penuh metafor. Sebagai konsekwensi dari latar tempat (Jawa Tengah), maka penuturan dalam dialog lakon ini lebih banyak menggunakan dialek Jawa Tengah (Solo) atau Jogyakarta.

\section{KONSEP PERANCANGAN}

Konsep perancangan dalam pementasan Lakon Senja dengan Dua Kelelawar karya Kirdjomulyo ini lebih dititik-beratkan pada penerapan aspek penyutradaraan. Dalam kaitannya dengan penyingkapan naskah, Yudiaryani membagi dalam dua pendekatan penyutradaraan, yaitu; pertama, presentasi yakni menghadirkan keseluruhan kenyataan ke atas panggung secara apa adanya. Kedua, gaya representasi merupakan pendekatan yang menghadirkan panggung sebagai interpretasi seluruh formula dan unsur-unsur pemanggungan yang secara kesejarahan telah hadir (Yudiaryani, 2002: 349). Merujuk pendapat tersebut maka konsep penyutradaraan dalam perancanag pementasan Senja dengan Dua Kelelawar karya Kirdjomulyo menggunakan pendekatan presentasi. Pendekatan presentasi itu pada akhirnya akan membingkai konsep artistik menjadi gaya pementasan yang presentatif pula. 
Berpijak pada gaya pementasan presentatif tersebut maka bentuk-bentuk pengadaptasian, pengolahan-pengolahan naskah secara 'radikal', perubahan-perubahan struktur dramatik (yang biasa dilakukan dalam pendekatan reprentasi) sama sekali tidak menjadi bagian dari konsep kerja penyutradaraan. Pijakan yang menjadi acuan dalam konsep penyutradaraan lakon Senja dengan Dua Kelelawar karya Kirdjomulyo adalah berpedoman pada jalinan konflik yang otentik dari naskah tersebut. Penambahan dan pengubahan dalam naskah hanya dilakukan dalam kadar yang tidak "melebarkan" atau "mempersempit" sruktur dramatik atau konflik dalam lakon. Penambahan tersebut lebih diorientasiakan pada pertimbangan dalam mempermudah komunikasi pertunjukan dengan penonton (audiens). Bentuk-bentuk pengubahan naskah tersebut antara lain dilakukan dengan pembakuan kalimat-kalimat dalam naskah agar semakin mengesankan bahasa percakapan, menambahkan dialog pada beberapa aktivitas para tokoh dalam lakon untuk menajamkan peristiwa. Dengan demikian secara keseluruhan, mekanisme kerja penyutradaraan dalam pementasan Senja dengan Dua Kelelawar masihlah mengarah pada upaya untuk memproyeksinya naskah ke dalam pementasan yang bergaya realisme.

Teater Realisme merupakan cerminan "sepotong kehidupan" yang ditampilkan secara detail namun apa adanya. Di atas panggung harus terbayang "sepotong kehidupan", a slice of life, sehingga seni panggung merupakan penyajian kembali kehidupan inderawi secara obyektif bahkan mendekati serinci mungkin dengan kenyataan (Bakdi Soemanto, 1986: 67). Itulah sebabnya, realisme berusaha mewujudkan apa yang disebut "ilusi realitas". Konsep ini menegaskan bahwa realisme harus mampu "memindahkan" kenyataan sehari-hari di atas panggung, bukan dalam bentuk menambahkan (stilisasi) atau merusak (mendistorsi), tetapi menyajikannya setepat mungkin sehingga ilusipun tercapai (Saini KM, 2002: 159). Konsep inilah yang melandasi transformasi lakon Senja dengan Dua Kelelawar karya Kirdjomulyo ke atas panggung, baik yang terlihat dari unsur pemeran maupun pada unsur penataan artistik

Titik fokus (emphasis) yang akan dicapai dalam perancangan lakon Senja dengan Dua Kelelawar karya Kirdjomulyo adalah berpijak dari tematis realisme secara umum. Chairul Anwar (2005: 88) menjelaskan bahwa secara tematis realisme menengarai keberadaan manusia sebagai makluk - sebagaimana yang diajarkan filsafat determinisme - yang tidak bebas memilih dan sangat ditentukan lingkungan. Dalam kontek ini, maka perancangan lakon Bui karya Akhudiat akan ditampilkan sebagai elaborasi sebuah kenyataan yang sering diusung lakon-lakon realisme: bahwa kebobrokan masyarakat harus diungkap. Setiap rentetan penyakit masyarakat harus dibawa ke permukaan dan romantisme yang tidak produktif harus di buang jauh-jauh. 
Realisme pada akhirnya menelurkan beberapa aliran dalam teater yang merupakan variannya. Varian yang paling menonjol adalah: naturalisme dan impresionisme. Perbedaan yang mendasar dari dua varian itu terletak pada gaya penuturan dalam lakon-lakonya. Mengenai dua varian tersebut, Saini KM (2002: 159) menjelaskan:

Jika naturalisme menampilkan manusia dalam kenyataan yang ilmiah, bersandar pada determinisme untuk menonjolkan fakta dan terlihat "garang" dalam memperlihatkan kemunafikan ataupun dekadensi moral, maka impresionisme menyimpan konflik-konflik itu secara lebih dalam tapi justru terkesan tajam dalam memperlihatkan derita manusia. Kalau naturalisme memberikan reaksi intelektualitas terhadap setiap persoalan dengan mendiskusikan dan memperdebatkannya, maka dalam impresionisme persoalan itu dipercakapkan, disinggungnya secara samarasamar bahkan terkadang dengan kelakar, tapi justru karena itulah tokoh-tokoh dalam lakonnya terkesan lebih "menghayati" dan mengesankan ironi yang mendalam.

Merujuk kutipan di atas maka secara umum drama realisme pada akhirnya bertujuan untuk membeberkan realitas tanpa melebihkan atau mengurangi. Dimensi kepahlawananpun ditinggalkan dengan cara memperlihatkan manusia kebanyakan yang nyata dan sering ditemui dalam keseharian, lengkap dengan carut-marut dan ke- bobrokannya. Dalam Kontek ini, maka lakon Senja dengan Dua Kelelawar karya Kirdjomulyo memiliki cakupan-cakupan dalam struktur lakonnya yang sangat memungkinkan untuk dihadirkan dalam sebuah pementasan yang berkarakter naturalis. Pencapaian karakter yang naturalis ini akan diperlihatkan melalui penyusunan suspen-suspen pementasan.

Dalam aspek pemeranan, maka pencapaian akting akan ditampilkan dengan pendekatan akting presentatif juga. Eka D. Sitorus (2002: 22) menjelaskan bahwa akting presentasi adalah akting yang mengutamakan identifikasi antara jiwa si aktor dengan jiwa si karakter, sambil memberi kesempatan kepada tingkah laku untuk berkembang. Tingkah laku yang dimaksud adalah pengembangan "laku" dalam imajinasi yang berasal dari situasi-situasi yang diberikan penulis lakon.

Untuk dapat mewujudkan akting presentasi, maka proses pencapaian peran dalam perancangan pementasan lakon Senja dengan Dua Kelelawar karya Kirdjomulyo akan "dihidupkan" melalui transformasi pengalaman-pengalaman dalam diri pemeran ke "dalam diri" tokoh yang ada di penokohan. Transformasi pengalaman tersebut bukan sebuah transformasi dari sederetan kejadian yang dialami pemeran secara langsung, tapi bisa juga pengalaman indrawi yang diperoleh secara tidak langsung baik melaui aspek auditif (pendengaran) maupun aspek visual (penglihatan). Hal tersebut ditujukan untuk menumbuhkan motivasi yang 
jelas dalam laku. Indikator penting dari tercapainya akting presentasi adalah kesesuaian psikologis tokoh dengan pemeran. Akting presentasi dengan demikian adalah melibatkan "apa yang ada dalam diri pemeran" ke dalam "situasi dan kondisi tokoh".

Dalam perwujudan gestur peran, akting dalam perancangan pementasan Senja dengan Dua kelelawar karya Kirdjomulyo ini lebih banyak menggunakan gestur indikatif, gestur empatik. Eka D. Sitorus (2002: 79) memberi batasan gestur indikatif sebagai bentuk gestur yang bertujuan untuk menegaskan keinginan yang bersifat informatif, dimana posisi peran (tokoh) sedang menjelaskan sesuatu. Gestur empatik adalah gestur yang diwujudkan sebagai akibat dari 'keterlibatan' tokoh dalam merespon suasana atau bereaksi pada aksi tokoh lain. Sedangkan gestur illustratif adalah gestur yang terstilir dimana gestur tersebut dipergunakan untuk menyampaikan informasi secara spesifik atau menggambarkan perilakuperilaku ekstrim dari tokoh-tokoh yang diperankan. Penggunaan gestur empatik dan indikatif dalam perancangan lakon Senja dengan Dua Kelelawar karya Kirdjomulyo dipergunakan pada saat tokoh-tokoh dalam lakon mampu melewati ketertekanannya secara wajar, yang hanya ditandai dengan dialog pertengkaran, hardikkan atau keluh kesah dan persaan sedih atau gembira saat menghadapi tekanan di penjara. Sedangkan gestur illustratif dipergunakan pada saat tokoh-tokoh dalam lakon terjebak pada perilaku-perilaku yang menyimpang seperti sikap kekanak-kanakan, perasaan terhadap keberadaan diri yang identik dengan hewan kerena beratnya tekanan, munculnya libido pada sejenis, dan dorongan dari ilusi-ilusi yang muncul sebagai kerinduan aktivitas aktivitas yang ditemui dalam alam kebebasan.

\section{METODE PENCIPTAAN}

Metode penciptaan teater yang dimaksud adalah merupakan cara kerja penyutradaraan yang diawali dari penafsiran naskah sampai dengan perwujudan pentas. Metode ini di mulai dari sasaran-sasaran yang bersifat pemahaman (kognitif) sampai pada penataan aspek-aspek 'material' pemanggungan dengan berpedoman pada gaya pementasan yang di pilih. Suyatna Anirun (2002: 115) menjelaskan bahwa proses kreatif penyutradaraan secara umum terbagi dalam empat langkah kreatif yang meliputi: tahap mencaricari; tahap memberi isi; tahap pengembangan dan tahap pemantapan.

\subsection{Tahap Mencari-cari}

Tahap mencari-cari merupakan rangkaian tindakan yang berpijak dari penggunakan aspek-aspek kognitif (Interpretation and Perseption) menuju pada pencarian kemungkinan-kemungkinan visual baik dalam bentuk penyusunan pola lantai keaktoran maupun pembuatan desain artistik. Aplikasi kongkret dari tahapan ini adalah analisis terhadap lakon baik dalam diskusidiskusi kolektif maupun dialog dua arah, yakni antara sutradara dengan pemain, 
sutradara dengan penata artistik dan suradara dengan penata musik. Langkah kerja berikutnya adalah penafsiran struktur lakon melaui reading yang dilakukan secara kolektif. Reading tersebut juga bertujuan dalam menjajaki kemampuan pemeran dalam kaitannya dengan tafsir pada tokoh, lebih khusus lagi pada pencarian karakter suara. Di luar proses kerja tersebut, tahap mencari-cari juga merealisasikan kembali berbagai latihan dasar pemeranan. Pelaksanaan latihan dasar pemeranan tersebut diarahkan untuk mencari kemungkinan-kemungkinan bagi gestur, analogi-analogi peran, dan menumbuhkan keterkaitan emosi terutama antar pemain. Bentuk latihan dasar tersebut antara lain: eksplorasi motif-motif gerak, olah rasa lewat pemaparan tematema tertentu, dan berbagai latihan pernafasan.

\subsection{Tahap Memberi Isi}

Tahap memberi isi merupakan rangkaian tindakan untuk mengembangkan aspek-aspek kognitif menuju pada aspek-aspek psiko-motorik. Pada tahap ini interpretasi lakon harus sedapat mungkin memberikan dorongan pemeran dalam mewujudkan akting verbal maupun non verbal berdasarkan desain akting yang bersifat global, yang telah disepakati sebelumnya. Penemuan penemuan yang masih bersifat 'kasar' tersebut, diolah untuk mendapatkan penekanan-penekanan yang mampu menggambarkan inti peristiwa, perubahan suasana dan progresi emosi tokoh-tokohnya. Penekanan-penekanan tersebut akan dihadirkan melalui penegasan pada sisi ekspresi mimik, impresi pada keseluruhan akting pemeran, laku yang memperlihatkan motivasi dan penyikapan terhadap areal permainan. Aplikasi pada metode ini direalisasikan pada latihan pencarian bloking, improvisasi-improvisasi di luar desain akting yang dijadikan pedoman, latihan diksi dialog yang mampu menggambarkan "perbedaan" tokoh sekaligus dinamika karakternya. Latihan pada tahap ini dilakukan dalam bentuk pemenggalan-pemenggalan naskah (fragmen) yang diperagakan secara berulang-ulang, dengan format yang dirubah-rubah. Latihan lain yang dilakukan pada tahap ini adalah dengan menghadirkan penggalan-penggalan tiap adegan tersebut melaui laku non verbal dengan meniadakan dialog yang semestinya dipercakapkan.

\subsection{Tahap Pengembangan}

Tahap pengembangan merupakan pengulangan-pengulangan terhadap tahapan memberi isi, yakni dengan mewujudkan movement, gesture, bussines act, dalam bentuk akting yang sudah memperlihatkan spontanitas. Akting spontan tersebut ditandai dengan perwujudan inner act pada keseluruhan tampilan para pemeran. Para pemeran di bimbing untuk merasakan situasi dalam diri tokoh yang diperankan melalui bentuk akting yang terlihat meyakinkan. Secara kongkrit bentuk latihan yang dilakukan dalam membangun keyakinan tersebut adalah latihan-latihan akting yang disertai 
pembangunan imajinasi terhadap latar cerita, kesadaran ruang, kesinambungan antara aksi dan reaksi, dan posisi kejiwaan pemeran yang memperlihatkan empati. Hal ini dilakukan dengan memaksimalkan keseluruhan tekstur permainan yang dapat memberikan imaji visual dalam indera dengar dan imaji auditif dalam indera penglihatan.

Dalam kaitannya dengan penataan illustratif maupun komponen artistik yang lain, maka para penata mengembangkan perancangan musik dan set dekornya berdasarkan konsepsi auditif dan imaji ruang yang telah diperolehnya dari pengamatan pada tekstur pemeranan yang telah terbangun. Konsep perancangan tersebut pada dasarnya merupakan pengembangan dari desain artistik dan partitur musik yang sebelumnya telah disimpulkan dari analisis teks atau lakon. Dengan demikian, dalam setiap latihan pengembangan, penata ilustrasi maupun penata artistik sudah dilibatkan secara intensif.

\subsection{Tahap Pemantapan}

Tahapan pemantapan merupakan rangkaian tindakan dalam kerja penyutradaraan untuk menampilkan lakon secara ansambel dan utuh. Orientasi latihan diarahkan pada penikmatan aspek irama, tempo, dan dinamika. Pusat konsentrasinya adalah pencapaian musikalitas dalam pementasan. Musikalitas tersebut di susun secara berulangulang (melalui latihan dari awal hingga akhir lakon) dengan mengacu pada pembenahan ketegangan demi ketegangan, timing pada perubahan suasana, lompatan-lompatan emosi tokoh, dan lambat-cepatnya dialog antar tokoh.

Pada tahap ini respon terhadap ruang (dengan segala set-dekornya) dan dukungan ilustrasi musik terhadap suasana demi suasana, sudah mulai dihadirkan dalam visualisasi yang masih global. Tujuan pengadaan set-dekor dan ilustrasi yang masih belum permanen ini adalah untuk mematangkan gestur pemain, membakukan jarak tempuh movement, dan menyeleksi berbagai unsur artistik dan musikalitas agar tercipta tata artistik dan tata musik yang mendukung permainan. Dengan demikian, pada tahap ini latihan-latihan telah melibatkan keselurahan unsur-unsur pementasan dalam sebuah ansambel yang utuh, yang diluar tujuan-tujuan di atas, juga diarahkan untuk menciptakan kesatuan yang harmoni.

\section{PEMENTASAN}

Tahapan pementasan merupakan penyajian keseluruhan unsur pentas dalam suatu pertunjukan yang utuh. Masing-masing unsur merupakan kekuatan yang saling terkait dalam menciptakan harmoni dan unity. Pementasan tersebut dilaksanakan di auditorium Bustanil Arifin Adam, STSI Padangpanjang, pada tanggal 22 Desember 2009 dengan durasi pentas berkisar 1 Jam 10 menit. Adapun unsur-unsur (bidang-bidang) yang akan ditampilkan dalam pementasan tersebut dapat dijelaskan sebagai berikut: 


\subsection{Penataan Set Dekor}

Set dekor dalam pementasan Senja dengan Dua kelelawar karya Kirdjomulyo ini berpedoman pada konsep perancangan secara keseluruhan yakni penghadiran lakon secara presentatif. Wujud kongkret dari perancangan secara presentatif tersebut adalah terjadinya kesesuaian antara Set dekor Senja dengan Dua Kelelawar karya Kirdjomulyo dengan pilihan bentuk pementasan, yakni realisme. Secara menyeluruh visualisasi setting diwujudkan sesuai penekanan (emphasis) dalam perancangan yang di rujuk dari tema lakon. Merujuk hal tersebut penataan set dekor dalam pementasan Senja dengan Dua Kelelawar karya Kirdjomulyo meliputi, sebuah Sebuah tebing sebagai penyangga rel kereta (di atasnya) yang memanjang dari pertengahan (samping) panggung ke arah sudut bagian belakang panggung. Di depan tebing tersebut terdapat kursi memanjang yang dapat diduduki ssua orang lebih dan di sampingnya terletak juga sebuah kursi kecil yang hanya bisa diduduki satu orang. Tebing penyangga rela menggambarkan tebing tembok yang telah kusam atau berlumut, sementara dibagian samping kanan nampak tiang listrik yang menjulang. Bahan-bahan yang digunakan untuk membuat setting ini meliputi: kertas kacang padi, kertas padang larang, kayu kerangka, cat sebagai pewarna dan penegas tekstur dinding dan sebilah kayu memanjang untuk pembuatan Tiang listrik.

\subsection{Penataan Cahaya}

Secara mendasar cahaya dalam pementasan ini berfungsi sebagai pendukung suasana kejadian, penanda waktu dan spasi adegan. Pada konteks penanda waktu tata cahaya diarahkan kepada pengaturan intensitas yang disesuaikan dengan waktu kejadian dalam lakon. Dalam fungsinya sebagai pendukung suasana lakon, lampu di desain dalam kombinasi warna tertentu. Sementara untuk spasi adegan, ada dua teknik yang biasa di gunakan dalam membuat perubahan cahaya dalam pertunjukan, yaitu fade in out dan black in out. Fade in out adalah penurunan dan penajaman secara lambat, sedangkan back in out adalah memulai dan mengakhiri adegan dengan mematikan atau menghidupkan cahaya. Impresi yang ingin dicapai dari penataan lampu adalah penghadiran suasana ruangan di malam hari dan memberi kesan 'suram'. Adapun jenis lampu yang digunakan dalam pementasan Senja dengan Dua Kelelawar karya Kirdjomulyo adalah fresnel, par dan zoom spot (elipsodal).

\section{PENATAAN MUSIK}

Karakter musik yang dipergunakan dalam Senja dengan Dua Kelelawar karya Kirdjomulyo adalah jenis musik yang disesuaikan dengan perubahan suasana dan penekanan-penekanan (suspen) dalam perjalanan alurnya. Pembentukan accord maupun melodi musik didasarkan pada musik tema yang dicipta dengan bertolak pada suasana dominan dalam lakon. Musik yang digunakan adalah beberapa jenis intru- 
men digital, antara lain gitar dan biola, dan orkestrasi yang lain.

Pada bagian awal pementasan musik yang diperdengarkan adalah efek suara kereta api. Sedangkan musik yang dipergunakan untuk ilustrasi adalah beberapa orkestrasi hasil olahan musik digital. Musik ilustrasi ini ditata sesusai alur musik (Music plot) yang penempatannya berpedoman pada penegasan dinamika suasana dalam lakon.

\section{PENATAAN RIAS DAN BUSANA}

Tata rias dan busana dirancang untuk memberikan penajaman karakter tokoh yang dimainkan para pemeran. Penegasan karakter tokoh itu meliputi penegasan secara fisikis dan sosial. Khusus untuk tata busana juga sangat penting untuk menggambarkan kondisi sosial tokoh-tokoh dalam lakon. Kondisi sosial yang dimaksud adalah sebuah lingkungan kelas menengah di sekitar stasiun kereta api. Adapun busana tersebut meliputi Pakaian seragam (uniform) yang biasa dipakai oleh Pegawai PJKA, pakaian malam yang biasa dikenakan bapak-bapak, beberapa pakaian batik (khas Jawa), pakaian wanita sehari-hari sederhana yang dikenakan Ismiyati dan Pakaian wanita glamour yang dikenakan Mursiwi. Sedangkan rias yang dipergunakan dalam pementasan Senja dengan Dua Kelelawar karya Kirdjomulyo meliputi dua jenis rias, yakni rias korektif dan rias karakter. Rias korektif ditampilkan pada tokoh Ismiyati dan Suwarto, sedangkan rias karakter digunakan pada tokoh pak Marsudi, Siswoyo, Tomokaryo dan
Mardikun. Adapun Mursiwi menggunakan rias wanita yang lebih berkesan 'menyolok'.

\section{PENUTUP}

Proses kreatif dalam seni teater pada dasarnya menempatkan aspek penyutradaran sabagai bidang kerja paling pokok. Seluruh jalinan materimateri pemanggungan, baik yang bersifat visual maupun auditif sangat dipengarihi oleh 'sentuhan' penyutradaraan. Sutradara dengan sendirinya, tidak sekedar harus menguasai aspekaspek pemanggungan (spektakel) tetapi juga harus mampu menerjemahkan secara tuntas gagasan-gagasan dasar yang tersirat dalam lakon sebagai titik tolak yang akan melandasi wujud pengemasan (gaya lakon).

Lakon Senja dengan Dua Kelelawar karya Kirdjomulyo menegaskan satu premis: bahwa nilai manusia tidak bisa dilihat dari 'permukaan' tetapi hanya bisa disimpulkan dari prilakunya dalam keseharian. Lakon ini menegaskan bahwa ketulusan cinta ternyata tidak sesederhana tutur kata, kehangatan sikap, perhatian berlebih dan kalimat-kalimat menghibur tetapi juga kesediaan untuk berkorban dan kerelaan untuk menerima orang yang dicintainya tersebut secara apa adanya. Inilah universalitas nilai yang sebenarnya sangat menarik untuk di kedepankan terlebih untuk mengaksentuasikan nilai-nilai islami sebagai karakter paling hakiki dalam spirit ke-Melayu-an.

Lakon Senja dengan Dua Kelelawar karya Kirdjomulyo adalah lakon 
yang bergaya realisme. Hal tersebut dapat disimak pada gaya dialognya yang masih keseharian, kejelasan identitas tokoh yang terlibat konflik, ketegasan dalam penggambaran latar cerita, dan suspen-suspen pertujukan yang menunjukan kausalitas yang jelas. Sebagai lakon Realime maka lakon ini memiliki berbagai kecenderungan sebagai lakon yang dapat digolongkan dalam well made play.

Berpijak pada gaya pementasan realisme (presentatif) tersebut maka bentuk-bentuk pengadaptasian, pengolahan-pengolahan naskah secara 'radikal', perubahan-perubahan struktur dramatik sama sekali tidak menjadi bagian dari konsep kerja penyutradaraan. Pijakan yang menjadi acuan dalam konsep penyutradaraan lakon Senja dengan Dua Kelelawar karya Kirdjomulyo adalah berpedoman pada jalinan konflik yang otentik dari naskah tersebut. Penambahan dan pengubahan dalam naskah hanya dilakukan dalam kadar yang tidak "melebarkan" atau "mempersempit" sruktur dramatik atau konflik dalam lakon. Penambahan tersebut ljuga ebih diorientasiakan pada pertimbangan dalam mempermudah komunikasi pertunjukan dengan penonton (audiens). Merujuk hal tersebut maka mekanisme kerja penyutradaraan masihlah mengarah pada upaya untuk memproyeksinya naskah ke dalam pementasan yang bergaya realisme.

Penjabaran pendekatan presentatif tersebut, diwujudkan dalam optimalisai keaktoran sebagai pusat perhatian tontonan, dengan penggunaan dua gesture pemeranan, sebagai gesture yang dominan yang dipakai dalam pementasan. Gesture tersebut meliputi gesture empatik dan gestur ilustratif. Gesture empatik dipergunakan saat para tokoh tampil dalam situasi 'wajar', dan pada saat para tokoh didera kesedihan atau kemarahan, sedangkan gesture ilustratif dipergunakan pada saat para tokoh berada dalam situasi tertekan yang memuncak.

Proses perwujudan pentas direalisasikan melalui suatu metode penyutradaran. Tahapan metode tersebut meliputi: tahap pencarian, tahap pemberian isi, tahap pengembangan dan tahap pemantapan. Tahap pencarian memiliki ruang lingkup kreativitas yang bertumpu pada penafsiran dan pemahaman lakon. Pemahaman dan penafsiran tersebut diwujudkan melalui penggambaran transformasi teks ke dalam pementasan melalui pembuatan desain akting, desain artistik dan perencanaan ilustrasi. Tahap pemberian isi dilakukan dengan menekankan motivasi aksi pada eksplorasi pemeranan. Tahapan pengembangan adalah membangun ujud permainan secara utuh dalam bingkai artistik secara menyeluruh, sedangkan tahap pemantapan adalah mewujudkan detail-detail pemainan sehingga seluruh elemen-elemen pertunjukan mampu tersajikan rapid dan padu. Tahapan ini menjadi pedoman dalam pelaksanaan latihan yang meliputi reading, bloking, dan Finishing.

\section{DAFTAR PUSTAKA}


Anirun, Suyatna. (2002), Menjadi Sutradara, Bandung: STSI Bandung Press.

(1993), Teater Untuk Dilakoni, Bandung: STB.

Anwar, Chairul. (2005), Drama, Bentuk, Gaya dan Aliran, Yogyakarta: Elkaphi.

Harymawan, RMA. (1988), Dramaturgi, Bandung: CV. Rosdakarya.

Saini, KM. (2002), Kaleidoskop Teater Indonesia, Bandung: STSI Press Bandung, 2002.

Sambung, Willy F. (1984), Pengetahuan Tentang Bentuk-bentuk Lakon, Bandung: CV. Rosdakarya.

Satoto, Sudiro, (1988), "Proyek Penelitian dan Pengkajian Kebudayaan Nusantara (Javanologi)" dalam Wayang Kulit Purwa, Struktur dan Dramatiknya, Yogyakarta: Pustaka Jaya.

Sitorus, D Eka. (2003), The art of acting: Seni Peran Untuk Teater, Film dan $T V$, Jakarta: Gramedia Pustaka Utama.

Soemanto, Bakdi. (1996), "Seni, Kritik, Sosial, Masyarakat" makalah seminar nasional Seni dan Kekuasaan, Agenda Kritis dan Introspeksi dalam Kultur Politik Orde Baru, SM-ISI Yogyakarta.

Stanislavsky, Konstantin. (1980), Persiapan Seorang Aktor, Terjemahan Asrul Sani Jakarta: Pustaka Jaya.

Sudjiman, Panuti. (1984), Kamus Istilah Sastra, Jakarta: PT Gramedia. (1988), Memahami Ceritacerita Rekaan, Jakarta: Pustaka Jaya.

Sumanto, Bakdi. (1991), "Memahami Naskah Lakon Absurd, Jurnal Pengetahuan dan Perancangan
Seni, Yogyakarta: BP ISI, edisi I/01, Mei 1991.

Sumardjo, Jacob. (1981), Segi Sosiologis Novel Indonesia, Bandung: Pustaka Prima.

Tim Penyusun Kamus Pusat Pembinaan dan Pengembangan Bahasa, (1996), Kamus Besar Bahasa Indonesia, Jakarta: Balai Pustaka.

Yudiaryani, (2002), Panggung Teater Dunia, Yogyakarta: Pustaka Gondho Suli. 